\title{
RHEUMATOID ARTHRITIS AND AMYLOID DISEASE
}

\author{
BY \\ BRANDON LUSH, I. S. CHALMERS, \\ and \\ ERNEST FLETCHER \\ From the Department of Rheumatism, Royal Free Hospital, London
}

(Received for publication July 19, 1948)

\section{Introduction}

The greater part of the literature on the occurrence of amyloidosis in rheumatoid arthritis and in Still's disease comes from the Western Hemisphere. Since the recent publication in this country of such a case by Yeoman and Wilson (1947) the interest of rheumatologists on this side of the Atlantic has been awakened and a watch has been kept for further cases. Over 200 cases of rheumatoid arthritis have been seen in the Rheumatology Unit of the Royal Free Hospital, and its predecessor the British Legion Unit, during the past year and a half. Several cases have for one reason or another been suspected of suffering from coincident amyloid disease, but only in one case has the diagnosis been established beyond doubt. This case is reported below.

\section{Case Report}

The patient, a married woman forty-four years old, was admitted to the Rheumatology Unit of the Royal
Free Hospital on July 2, 1947, complaining of pains in the joints. Three months earlier she had woken up one morning with a severe pain in the right knee. Up to that time she had been perfectly well in evefy respect. The knee continued to be very painful, even at rest. A few days later the temporo-mandibular joints and the neck became stiff and painful. Shortly afterwards the left wrist and knee became swollen and painful, with the result that she had to retire to bed, where she remained until her admission to hospital: During that period she felt febrile, sweated excessively, and steadily lost weight. Her menstruation was normal until her admission to hospital, since when there has been complete amenorrhoea.

The only illnesses that she had suffered in the past were an attack of " acute eczema" in 1939, which lasted for three months, including a ten weeks' stay in hospital, and a fracture of the left hip in 1946, which healed uneventfully.

There was nothing relevant in the family history. The patient has three children.

When examined on admission she was seen to be very

TABLE 1

BLOOD PICTURE CHANGES

\begin{tabular}{|c|c|c|c|c|c|c|c|c|}
\hline Date & $\mathrm{Hb}$ & $\begin{array}{l}\text { Red blood } \\
\text { cells } \\
\text { (per c.mm.) }\end{array}$ & $\begin{array}{c}\text { White } \\
\text { blood cells } \\
\text { (per c.mm.) }\end{array}$ & $\begin{array}{c}\text { Polymorpho- } \\
\text { nuclears }\end{array}$ & $\begin{array}{l}\text { Lympho- } \\
\text { cytes }\end{array}$ & $\begin{array}{l}\text { Mono- } \\
\text { cytes }\end{array}$ & $\begin{array}{c}\text { Eosino- } \\
\text { phils }\end{array}$ & $\begin{array}{l}\text { Baso- } \\
\text { phils }\end{array}$ \\
\hline 3.7.47 & 62 & - & 7,000 & - & - & - & - & - \\
\hline 14.7.47 & 73 & $3,810,000$ & 7,000 & - & - & - & - & - \\
\hline 1.9 .47 & 56 & - & - & - & - & - & - & 一 \\
\hline 7.9.47 & 65 & - & - & - & - & - & - & 一 \\
\hline 16.9.47 & 70 & $4,690,000$ & 9,000 & $\overline{70}$ & $\overline{02}$ & - & - & - \\
\hline 6.11 .47 & 76 & $4,900,000$ & 9,000 & 70 & 23 & 4 & 3 & $\mathbf{0}$ \\
\hline $\begin{array}{l}14.11 .47 \\
21.11 .47\end{array}$ & $\begin{array}{l}64 \\
83\end{array}$ & $4,650,000$ & 5.000 & 73 & 21 & 4 & 2 & 0 \\
\hline 10.12 .47 & 72 & $4,600,000$ & - & 15 & & & & \\
\hline 23.12 .47 & 87 & $4,850,000$ & - & - & - & - & - & - \\
\hline 6.1 .48 & 71 & - & 5,000 & 74 & 20 & 2 & 4 & 0 \\
\hline 19.1 .48 & 75 & $\overline{0}$ & 8,500 & 68 & 27 & 5 & 0 & 0 \\
\hline $\begin{array}{l}21.1 .48 \\
192.48\end{array}$ & $\overline{72}$ & $4,600,000$ & 一 & 一 & - & - & 一 & 一 \\
\hline 1.3 .48 & 91 & $5,4 \overline{60,000}$ & 10,000 & 69 & 26 & 5 & $\overline{0}$ & $\overrightarrow{0}$ \\
\hline
\end{tabular}


pale and apathetic, and she looked ill. Her temperature was $100 \cdot 4^{\circ} \mathrm{F}$, and pulse rate 96 per minute. The elbows, wrists, fingers, and knees showed the typical changes of rheumatoid arthritis, the joints being hot, swollen, and painful. Nothing abnormal could be detected in the cardiovascular or central nervous system. The blood pressure was $120 / 80 \mathrm{~mm}$. Hg. A few non-persistent crepitations were heard at the left apex, but otherwise there were no abnormal findings in the respiratory system. She wore complete dentures. The tongue was clean and the throat appeared normal. The abdomen was normal.

Clinical Course.-The Ear, Nose, and Throat and Gynaecological Departments reported that nothing abnormal could be found, apart from a purulent vaginal discharge which rapidly cleared up.

The white cell count was within normal limits and remained so throughout (Table 1). The patient was diagnosed as suffering from early acute rheumatoid arthritis and was placed on the following treatment: calcium aurothiomalate, 0.01 g. weekly; vitamin D (high potency irradiated ergosterol), 200,000 international units daily for 28 days; TAB vaccine intravenously (see later); night splints to prevent further deformity of the hands; and other physiotherapeutic measures (Table 2). The patient was febrile on admission and remained so for two hundred days. (A portion of the temperature chart, which is typical of the whole period, is reproduced.)

The diagnosis of rheumatoid arthritis was considered established and it was thought that this might be responsible for the continued fever. However, a very thorough search was made for other causes of continued pyrexia. Agglutination reactions, chest investigations, urinalysis, blood culture (Table 3) all failed to throw any further light on the cause of the fever. Even with a high calorie diet and more than adequate vitamin supplements the

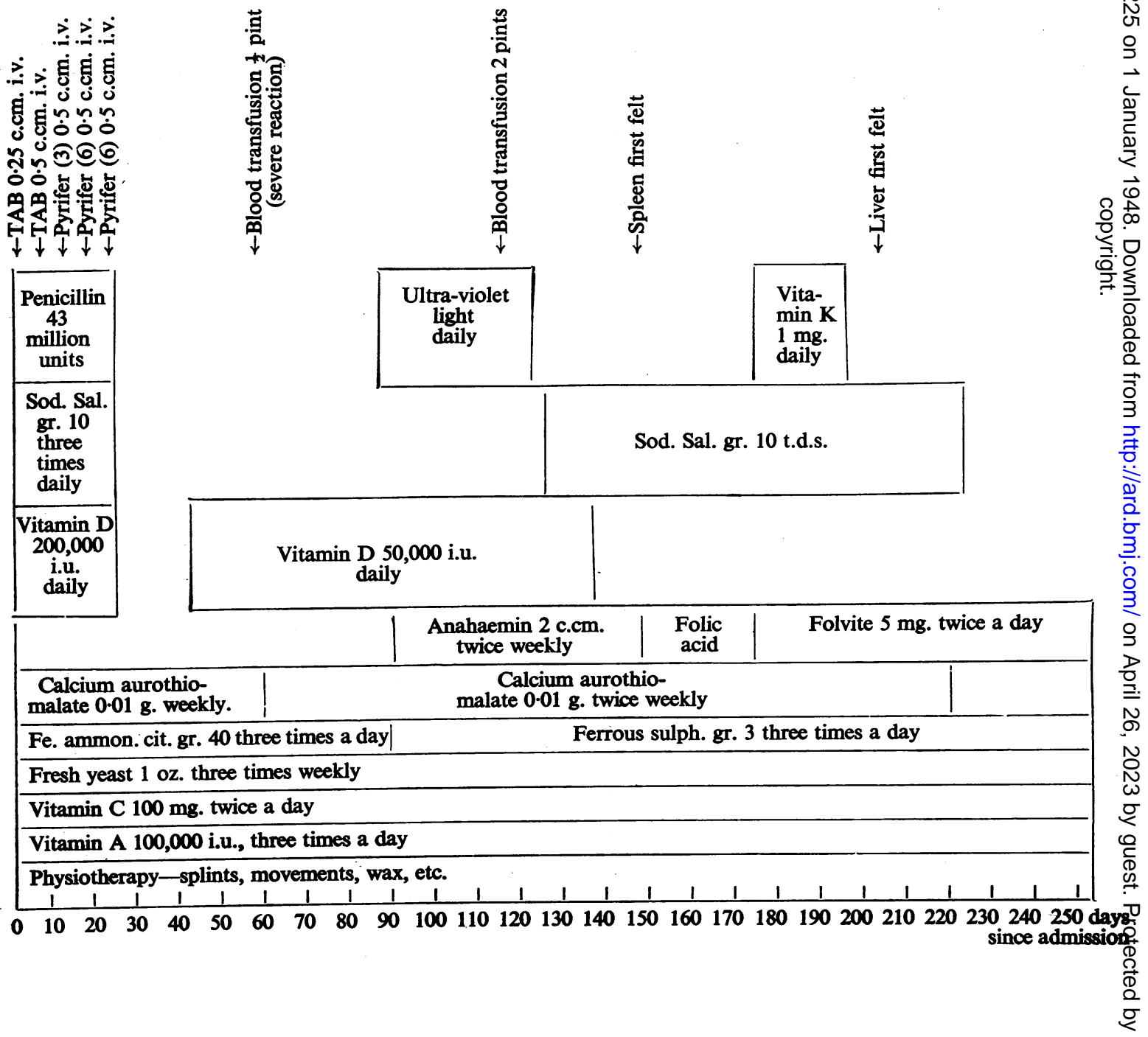

TABLE 2

RECORD OF TREATMENT

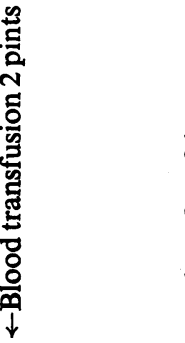


patient's general condition slowly deteriorated. In spite of iron and liver therapy and a blood transfusion, the anaemia did not improve until she was given folic acid, when her haemoglobin level began to rise for the first time. This may well have been coincidental, for no deterioration has followed the withdrawal of folic acid, and it coincided with a general improvement.

Artificial fever therapy consisted of two intravenous injections of TAB vaccine $(100$ million organisms per c.cm.) and three of a proprietary preparation of $B$. coli vaccine (1,000 million organisms per c.cm.). An adequate peak temperature was produced each time and her joint condition improved slightly.

On Sept. 3 the patient was given a blood transfusion with compatible blood, which had been cross-matched. However, owing to a severe rigor (peak temperature $104^{\circ} \mathrm{F}$.) it had to be discontinued after only half a pint had been given. Subsequent examination of the urine showed no haemoglobin derivatives.

From Oct. 2 she was given a course of generalized ultra-violet light; this produced a deep pigmentation of the skin, which has persisted.

The serum protein levels, estimated on Oct. 9, tended to be abnormal, the albumin/globulin ratio being low (Table 3).

On Nov. 6 a transfusion of 2 pints of group $\mathrm{O}$ blood was given without untoward effect. Prior examination of the blood had shown the absence of any abnormal agglutinins which might have been responsible for the reaction to the earlier transfusion. (The most likely cause was excessive rouleaux formation due to high blood-fibrinogen level following TAB therapy.)

Two weeks later the spleen and lymph glands (axillary and inguinal), but not the liver, became palpable for the first time. The following possible diagnoses were at that time considered in turn: Felty's syndrome, coincident Hodgkin's disease, amyloidosis, and the splenomegaly and adenopathy that sometimes accompanies rheumatoid arthritis. In the absence of any leucopenia or pigmentation before ultra-violet light therapy, it was felt that

TABLE 3

RECORD OF INVESTIGATIONS

\begin{tabular}{|c|c|c|c|}
\hline Date & Investigation & Date & Investigation \\
\hline 3.7 .47 & $\begin{array}{l}\text { No gynaecological or E.N.T. abnormalities } \\
\text { found. }\end{array}$ & 7.9 .47 & $\begin{array}{l}\text { Catheter specimen of urine: no abnormality; } \\
\text { no blood pigment derivatives present. }\end{array}$ \\
\hline 7.7 .47 & $\begin{array}{l}\text { Sputum : scanty epithelial cells present; no } \\
\text { tubercle bacilli. } \\
\text { Agglutination reactions: serum does not } \\
\text { agglutinate with } B \text {. abortus, } S \text {. typhi, } S \text {. } \\
\text { paratyphi, } \mathrm{H} \text { and } \mathrm{O} \text {, or non-specific sal- } \\
\text { monellae. }\end{array}$ & $\begin{array}{l}17.9 .47 \\
24.9 .47 \\
6.10 .47 \\
9.10 .47\end{array}$ & $\begin{array}{l}\text { Occult blood test: negative } \\
\text { Blood group: A; Rh positive; no anti-Rh } \\
\text { agglutinins. } \\
\text { X-ray: decalcification of hands, wrists, and } \\
\text { left knee. } \\
\text { Serum proteins: }\end{array}$ \\
\hline 8.7 .47 & $\begin{array}{l}\text { Catheter specimen of urine: nothing abnormal. } \\
\text { Cervical swab: scanty epithelial cells present. } \\
\text { Scanty gram-positive cocci and bacilli } \\
\text { present. Scanty Staph. aureus (coagulase- } \\
\text { negative). }\end{array}$ & & $\begin{array}{l}\text { Total proteins } 6.56 \mathrm{~g} \text {. per } 100 \mathrm{c} . \mathrm{cm} \text {. Albumin/ } \\
\text { globulin ratio } 1.1 / 1.0 \text {. } \\
\text { Serum albumin } 3.48 \mathrm{~g} \text {. per } 100 \mathrm{c} . \mathrm{cm} \text {. Formol } \\
\text { Gel test-negative. } \\
\text { Serum globulin } 3.08 \mathrm{~g} \text {. per } 100 \mathrm{c.cm} \text {. }\end{array}$ \\
\hline 10.7 .47 & $\begin{array}{l}X \text {-ray sinuses: nothing abnormal. } \\
\text { Wassermann reaction, Khan reaction, and } \\
\text { Gonococcal complement-fixation tests: all }\end{array}$ & 6.1 .48 & $\begin{array}{l}\text { Erythrocyte sedimentation rate (Wintrobe): } \\
46 \mathrm{~mm} \text {. in } 1 \text { hour. Cell volume } 35 \text { per cent.; } \\
\text { corrected ESR. } 20 \mathrm{~mm} \text {. in } 1 \text { hour. }\end{array}$ \\
\hline 12.7 .47 & $\begin{array}{l}\text { negative. } \\
\text { Blood cultures: one negative; the other } \\
\text { showed a slight growth of Staph. albus (pro- } \\
\text { bably a contaminant). } \\
\text { Faeces: no pathogens isolated. } \\
\text { Sputum: scanty epithelial cells present; } \\
\text { no tubercle bacilli. }\end{array}$ & 27.1 .48 & $\begin{array}{l}\text { Report on specimen: the yellow material from } \\
\text { the skin consists of keratinized squamous } \\
\text { cells only. } \\
\text { Blood cholesterol: } 113 \mathrm{mg} \text {. per } 100 \mathrm{c} . \mathrm{cm} \text {. } \\
\text { Dr. Lee Lander reported that the prolonged } \\
\text { fever could not be due to the chest con- } \\
\text { dition. }\end{array}$ \\
\hline 28.7 .47 & $\begin{array}{l}\text { Sputum: scanty epithelial cells present; no } \\
\text { tubercle bacilli. } \\
\text { Erythrocyte sedimentation rate (Wintrobe): } \\
64 \mathrm{~mm} \text {. in } 1 \text { hour. Cell volume } 28 \text { per cent. } \\
\text { Corrected erythrocyte sedimentation rate } \\
34 \mathrm{~mm} \text {. in } 1 \text { hour. }\end{array}$ & 29.1.48 & $\begin{array}{l}\text { Report on biopsy of axillary gland: marked } \\
\text { amyloid degeneration affecting mainly the } \\
\text { centres of the lymph follicles. In addition, } \\
\text { the gland shows some reticulo-endothelial } \\
\text { hyperplasia (sinus catarrh). } \\
\text { Serum proteins: }\end{array}$ \\
\hline 2.8 .47 & $\begin{array}{l}\text { Sputum: scanty epithelial cells present. No } \\
\text { tubercle bacilli. } \\
\text { Throat swab: no haemolytic streptococci, but } \\
\text { numerous } M \text {. catarrhalis and scanty Strep. } \\
\text { viridans. } \\
\text { Blood group: A. }\end{array}$ & 11.2 .48 & $\begin{array}{l}\text { Total proteins } 8.0 \mathrm{~g} \text {. per } 100 \mathrm{c} . \mathrm{cm} \text {. Albumin/ } \\
\text { globulin ratio } 1.8 / 1 \cdot 0 \text {. } \\
\text { Serum albumin } 5 \cdot 1 \mathrm{~g} \text {. per } 100 \mathrm{c} . \mathrm{cm} \text {. } \\
\text { Serum globulin } 2.9 \mathrm{~g} \text {. per } 100 \mathrm{c} . \mathrm{cm} \text {. } \\
\text { Catheter specimen of urine: nothing abnormal. } \\
\text { Blood urea: } 24 \mathrm{mg} \text {. per } 100 \mathrm{c} . \mathrm{cm} . \\
\text { Urea clearance test: } 60.5 \mathrm{c} . \mathrm{cm} . / \mathrm{min} .=11.5 \\
\text { per cent. normal. } \\
\text { Congo-red test: less than } 10 \text { per cent. present } \\
\text { in the serum after } 60 \text { minutes. }\end{array}$ \\
\hline
\end{tabular}


little would be gained by diagnosing Felty's syndrome. Hodgkin's disease was thought to be a possible diagnosis, since both the spleen and the glands were very hard, and amyloidosis was thought remotely possible. It was felt that biopsy of one of the enlarged axillary glands should be the next step in the investigation, and this was done on Jan. 16, 1948. The biopsy (see illustration) established the diagnosis of amyloidosis, and a Congo-red absorption test confirmed it ( 90 per cent. of the dye was removed from the blood stream in one hour and none was lost via the kidney).

For the first two hundred days after admission the patient's condition continued to deteriorate. Loss of weight was slow but steady and she remained febrile throughout. The liver, spleen, and lymph glands progressively enlarged. There had been no sustained response to any form of treatment. Coincident with the commencement of treatment with crude liver extract the patient became afebrile for the first time (and has remained so since); she began to put on weight, the spleen and lymph glands grew smaller and her general condition improved greatly. However, the liver has, if anything, continued to increase in size. Rheumatoid arthritis runs such an erratic course that it is impossible to draw any conclusions from the results of treatment in one case, but it is considered that the use of crude liver extract is worth trying in cases of amyloidosis complicating rheumatoid arthritis.

\section{Discussion}

The first reports of amyloidosis in rheumatoid arthritis were published almost simultaneously by Spitzy and Whitman in 1903. Subsequent reports have appeared sporadically since. Trasoff and others (1944) state that they have been able to trace the reports of thirty-one cases of amyloidosis in Still's disease, and Yeoman and Wilson (1947) state that about thirty cases of amyloidosis have been reported in rheumatoid arthritis. However, it is probable that the true incidence is higher. Goldthwait (1940) mentions amyloidosis as an incidental finding in an extraordinarily high percentage (21 per cent.) of autopsies on cases of rheumatoid arthritis. Bach and Savage (1940) mention finding evidence of amyloid tissue in two of the three spleens removed from severe cases of rheumatoid arthritis during life in an endeavour to control the disease. Ungar (1947) mentions finding Congo-red absorption figures diagnostic of amyloidosis in six cases of irheumatoid arthritis, but they did not consider the finding worthy of further comment. These cases are not included in the above figures. As has been mentioned already, only one case has been found among the first two hundred cases of rheumatoid arthritis in this Unit. Thus, though the association cannot be termed a common one, the true incidence remains doubtful.

The next question is the significance of the association. Is amyloidosis in rheumatoid arthritis as much an incidental finding as, for instance, pulmonary tuberculosis? Or is there some aetiological connexion? Comroe (1944) states that amyloidosis has been reported in pulmonary tuberculosis, chronic suppuration, Hodgkin's disease, leukaemia, myelomatosis, cirrhosis of the liver, malaria, syphilis, polyarteritis nodosa, rheumatoid arthritis, and Still's disease. All these conditions have in common a disturbance in protein metabolism. Magnus (1947) mentions rapidly-growing tumours as a further cause of amyloidosis. Again, one can implicate disturbance of the body protein, since the drain of protein with a rapidly-growing cellular tumour must be enormous. There is another much rarer condition in which amyloid tissue may be found, that is, primary amyloidosis, but it presents an entirely different clinical picture. Primary amyloidosis affects mainly the tongue, oesophagus, heart, and pericardium. The amyloidosis occurring in rheumatoid arthritis is invariably of the secondary type, which is a point in favour of its being as truly secondary as that in chronic osteomyelitis, for instance.

Fletcher (1947) mentions that many workers have found some abnormality on examination of the plasma proteins in cases of rheumatoid arthritis, the commonest being an increase in the blood fibrinogen or globulin. Similar changes may occur in various liver diseases, amyloidosis, myelomatosis, and leishmaniasis. In searching for cases of amyloidosis among our cases of rheumatoid arthritis we have taken the clinical picture into consideration first. Where such findings as enlargement of liver, spleen, or lymph glands, unexplained oedema, or albuminuria have occurred, we have had the blood proteins estimated. If they have been abnormal, then other liver function tests have been performed. In all cases to date where this has been done, the result has been within normal limits, which is suggestive that the abnormal plasma protein levels occurring in some cases of rheumatoid arthritis are not due to liver dysfunction, neither, with the one exception mentioned above, do they seem to be due to incipient amyloidosis, since we have performed Congo-red tests in all cases where the plasma protein levels have been markedly abnormal (we have had cases with a total plasma protein level as high as $9 \cdot 1 \mathrm{~g}$. per $100 \mathrm{c.cm}$., and a globulin level of $5.5 \mathrm{~g}$. per $100 \mathrm{c.cm}$.). In our limited experience it does seem that the altered plasma protein levels in severe chronic rheumatoid arthritis cannot readily be explained by any recognized mechanism. It is generally accepted that both plasma protein changes and amyloidosis occur only in severe and chronic (more than two years' duration) cases (Trasoff and others, 1944). However, if 
our patient's story is to be believed-and she is an intelligent person-then the plasma protein changes and amyloidosis have developed in a matter of months from the onset of rheumatoid arthritis.

It has been suggested that amyloidosis is due to long-continued hyperglobulinaemia (Trasoff and others give several references), but in Trasoff and others' case the onset of amyloidosis well preceded any change in the plasma proteins, and in our case there was no marked hyperglobulinaemia. Also, we have had many cases, such as the one mentioned above, of continued gross hyperglobulinaemia without any evidence of amyloidosis.

Other suggestions as to the cause of amyloidosis in rheumatoid arthritis include TAB vaccine therapy
(Reimann and Eklund, 1935; Goldthwait, 1940) and chrysotherapy. However, our case had very little in the way of artificial fever therapy compared with many others (Goldthwait's case had had forty-one TAB injections in twenty-two months, and we have had a number who have had up to eight at various times). Trasoff and others' case had had no chrysotherapy, and Yeoman and Wilson's only fifteen gold injections. Thus it is difficult to implicate gold. However, it does seem possible that TAB injections may be a factor in the aetiology of some, but certainly not all cases, of amyloidosis in rheumatoid arthritis. The other therapeutic measures that our patient had received are so commonly used without ill effect that it seems difficult to incriminate them, unless

Right.-Low-power view of the cortex of an axillary lymph gland showing the deposition of amyloid tissue in relation to the arterioles.

Below.-Section of the temperature chart.
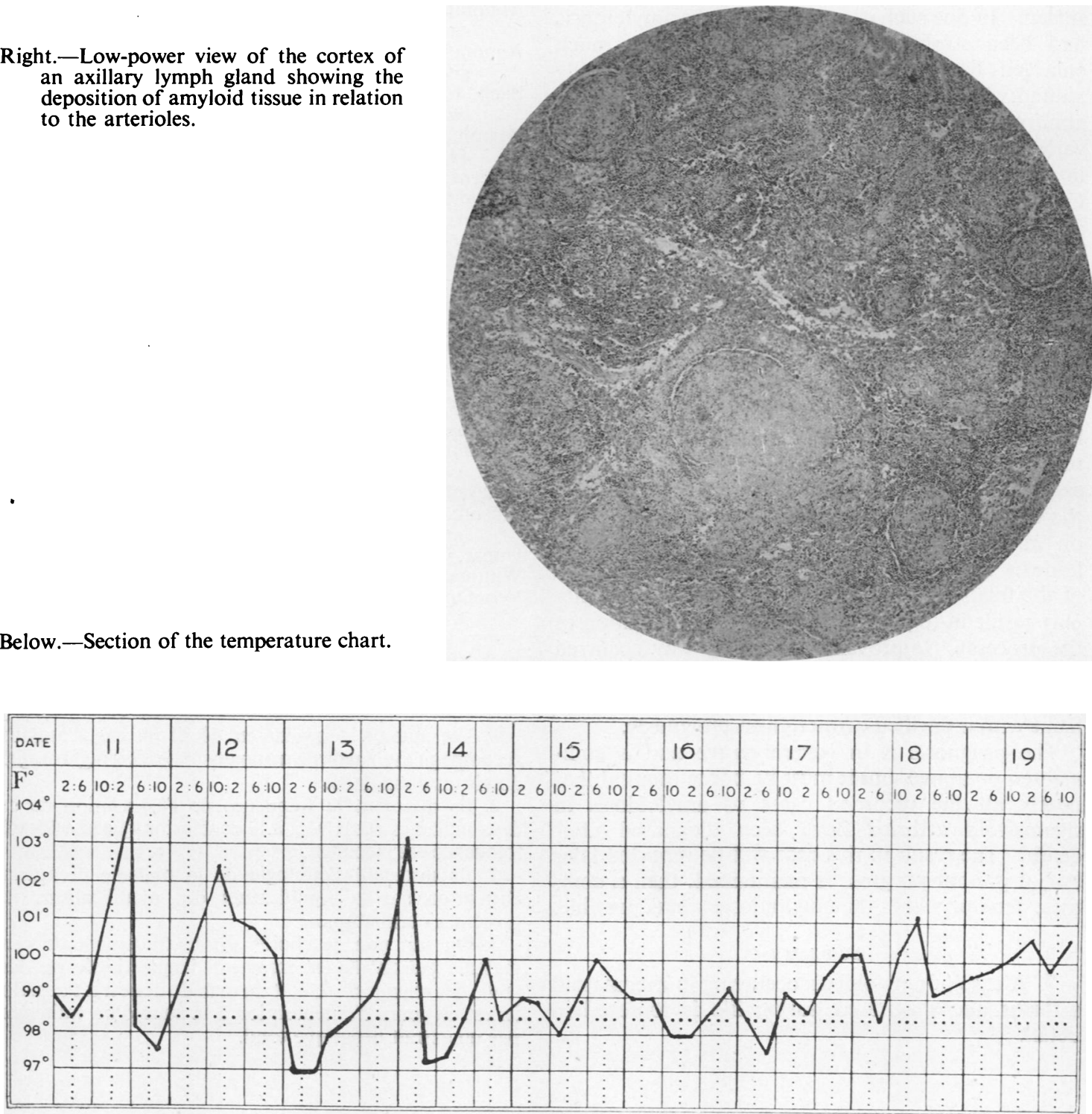
one postulates that the patient is hypersensitive to them, which would raise the question of allergy; but amyloidosis has none of the features of an allergic disease.

Amyloid tissue is, like mucin, a glycoprotein and it may be that therein lies the clue to the aetiology of the disease, since there is some evidence that mucolysis occurs, in the joints at any rate, in rheumatoid arthritis.

Recent work (Dougherty and White, 1947; Brit. med. J., 1945; Lancet, 1948) has shown that the serum globulin may be formed in part, if not in whole, from the lymphocytes and it is interesting, in view of this, to find that many chronic severe cases of rheumatoid arthritis have both an increase in the serum globulin and palpable lymph glands and spleen. In one such case of ours, where amyloidosis had been strongly suspected, biopsy of a much enlarged lymph gland showed it to be literally stuffed with lymphocytes but otherwise to show no abnormality. This finding correlates with that of various workers who have performed splenectomy in rheumatoid arthritis (Bach and Savage, 1940; Craven, 1934; Hanrahan and Miller, 1932; Loeper and others, 1937), for in all cases lymphoid hyperplasia in an enlarged spleen was found. All cases were severe, chronic, and intractable. It is possible that this lymphoid hyperplasia and hyperglobulinaemia may be an attempt to produce antibodies against a severe infection-a point in favour of the infective theory of origin of rheumatoid arthritis.

With regard to treatment there is little that is known to have any effect. Trasoff and others' case recovered completely on treatment with crude liver extract and they comment that liver injections are the only form of therapy known to have any effect on amyloidosis in rheumatoid arthritis (in amyloidosis secondary to chronic suppuration, removal of the focus by, for instance, amputation of a limb, may result in regression and complete resolution of the process). Improvement in every way occurred in our case when treatment with crude liver extract was begun. No improvement had followed treatment with a purified extract given previously.

The prognosis is in general grave and is commented on above, but it must be borne in mind that nearly all the recorded cases of amyloidosis in rheumatoid arthritis have been diagnosed after death. The result in this case will be reported later but, if present progress is maintained, then a complete recovery from the amyloidosis seems possible.

\section{Summary}

1. A case of amyloidosis occurring in rheumatoid arthritis and diagnosed during life is reported in detail.
2. The incidence of the association of the two conditions is discussed, the conclusion being that the true incidence remains unknown.

3. The aetiology of the condition is discussed, attention being drawn to the significance of the plasma protein changes.

4. Little is known of treatment, since the condition is seldom diagnosed during life. The present case is improving on treatment with crude liver extract.

Our thanks are due to various colleagues who assisted us in this investigation, and especially to $\mathrm{Mr}$. George Qvist, F.R.C.S., who carried out the biopsy, and to Dr. Marjorie Gillespie for her excellent histological diagnosis.

\section{REFERENCES}

Annotation (1945). Brit. med. J., 2, 223. (Full references given.)

Annotation (1948). Lancet, 1, 412. (Full references given.)

Bach, F., and Savage, O. (1940). Annals of the Rheumatic Diseases, 2, 47.

Carroll, J. H., and Nelson, R. L. (1927). Arch. Paediat., 44, 187.

Comroe, B. I. (1944). "Arthritis and Allied Conditions." London.

Craven, E. B. (1934). J. Amer. med. Ass., 102, 823.

Dougherty, T. F., and White, A. (1947). J. Lab. clin. Med., 32, 584.

Fletcher, E. T. D. (1947). " Medical Disorders of the Locomotor System." Edinburgh. P. 223.

Goldthwait, J. S. (1940). New Engl. J. Med., 223, 568.

Hanrahan, E. M., and Miller, S. R. (1932). J. Amer. med. Ass., 99, 1247.

Loeper, M., Lemaire A., and Patel, J. (1937). Pr. Med., 45, 625 .

Magnus, H. A. (1947). Personal Communication.

Reimann, H. A., and Eklund, C. M. (1935). Amer. J. med. Sci., 190, 88

Spitzy, H. (1903). Z. Orthop. Chir., 2, 699.

Trasoff, A., Schneeberg, N., and Scarf, M. (1944). Arch. intern. Med., 74, 4.

Ungar, G. (1947). Lancet, 1, 708.

Whitman, R. (1903). Med. Rec., 63, 601.

Yeoman, W., and Wilson, J. V. (1947). Brit. med. J., 2, 483 .

\section{Arthrite Rhumatismale et Maladie Amyloide}

\section{RÉSUMÉ}

1. Les auteurs décrivent en détail un cas d'amylose accompagnant l'arthrite rhumatismale et diagnostiquée du vivant du malade.

2. Ils discutent la fréquence de l'association de ces deux maladies et arrivent à la conclusion que sa véritable fréquence est inconnue.

3. Ils discutent l'étiologie de la maladie et attirent l'attention sur la signification des modifications des protéines plasmatiques.

4. On sait peu de choses sur le traitement de cette maladie puisqu'elle est rarement diagnostiquée pendant la vie des malades. L'état du malade dont il est question ici est en cours d'amélioration à la suite d'un traitement par un extrait hépatique total. 